\title{
Extraction of Evaluation Factors on the Conflicts of Interests in Coastal Area
}

\author{
Ki-Tae Yeo* $\cdot$ Hui-Gyun Jeong ${ }^{* * *} \cdot \mathrm{Gi}^{-}$Chul $\mathrm{Yi}^{* * * *} \cdot$ Sang-Hyun Suh ${ }^{* * * * *} \cdot$ Chang-Ho Park ${ }^{* * * * *}$ \\ * Department of Distribution and Trade Woosuk University, Chonbuk 565-701, Korea \\ ** DIMARS Co, Ltd. Ssangyong Research Institute, Daejeon 305-804, Korea \\ *** Dept. of Urban Planning and Landscape Architecture, DongA University, Busan 602-714, Korea \\ ***** KORDI, Daejeon 305-343, Korea \\ ****** Inchon Development Institute, Inchon, 404-190, Korea
}

\begin{abstract}
Currently serious conflicts of interests are arisen for the use of coastal area in Korea. However, there are no mediation program, mediators' activities, consistent policies and reasonable laws to resolve conflict of interests which may be arisen when developing coastal area. The objective of this study is to lay the evaluation criteria for the formalized objective evaluation among disputants of coastat conflicts for the better understanding and characterizing of coastal conflicts in Korea. In order to do so, this study has adopted for the extraction of the evaluation factors to describe the present conditions of conflicts in the selected study area(Sitwa lake), to analyze the problems, and then to explore alternative approaches for resolving the conflicts. As research methodologies, we have depended upon literature review and field survey methods. As field survey methods, we employed structured questionnaires for the various samples from the experts of research institutes, professors, representatives of NGOs and citizens. Survey results suggested that 5 representative elements comprising 35 detailed elements could be identified. Based on these results, this study was able to identify and classify the evaluation factors and help to resolve coastal conflicts in Korea.
\end{abstract}

Key words : Coastal area, Conflicts resolution, Mediator, PCA(Principal Component Analysis), Evaluation Factors

\section{Introduction}

The conflicts related to the usage, preservation, and development of coastal areas lies in the empirical elements around the resources. In other words, speaking in plane geometry, a single land resource can only be used for single application, on the other hand, coasts can be used for various applications, therefore land usage and resource conflicts arise from these resources(Sorensen, J. C., 1990), (Cicinsain B., 1992). In order to resolve these issues, it is necessary to control the development environment as well as the environment elements in general consideration of the complex factors, and also expand the coastal use direction to enhance the quality of life of the local citizens(Bower B. D., Turner R. K., 1998). However, the current situation is in a state where there are insufficient mediators for the objective and reasonable mediation and resolution of the conflicts in interest with an evaluation factores between the conflicting parties of the coastal area for development and preservation, resulting in serious problems at the national and local level for confliction(Keum J. S., Yoon M. O, 1998). Generally, a conflict is defined as the state where plural entities do not agree over a specific matter. The broad definition for interest conflict includes all the social issues and disputes conceptually, while the narrow definition means only the dispute above the social issues(Kim K. S., 1999).

Usually the conflict can be divided into inter-governmental conflict and local conflict, and the inter-governmental conflict can again be divided into the conflict between the central government and the local governments, and the conflict between the local government themselves. The local conflict can also be divided into the conflict between the local government and the citizens, and the enforcement and the citizens(environment organizations).

Conflicts of various entities are arising in the coastal area which is the target of this study. Our country's conflicts in the coastal area can be largely divided into the usage/development issues and the preservation issues. Usage/development issues can be divided into industrial usage related issues, water-friendly leisure usage related issues, urban usage related issues etc., and preservation issues can be divided into historical monument related issues, pollution prevention and ecosystem preservation related issues etc(Schneider P., Tohn E., 1985), (Young M. D., 1992), (Park C. H., Rho H. S., Yang W. J., 1998). In the domestic case, recently a social issue had risen concerning the problematic development of the Semangum district including lake Siwha, which was due to the demand of

\footnotetext{
*** Corresponding Author : Gi-Chul Yi, gcyi@daunct.donga.ac.kr, 051)200-7669

* ktyeo@woosuk.ac.kr, 063)290-1420

** jhg@dimas.co.kr, 042)865-1882

**** shsuh@kriso.re.kr, 042-868-7264

****** chpark@idi.re.kr, 032-560-5821
} 
development between various departments of the government. Currently, in the viewpoint of individual laws, various development, usage, preservation plans are in conflict since over 1000 business plans are planned and established in identical coastal areas(Jo D. O., 2001).

Some examples of resolved areas of conflict between entities through mediation and control tasks are the Kumgang rivermouth, Sunchun bay, lake Seokho, and an example where there still exists serious conflicts of development, usage, preservation and currently not able to find a solution, is the Siwha lake area. In this view, this study aims for proposing an objective and standard evaluation method to extract reasonable decision making of the conflict area through mediation and control tasks in the coastal area applications of our country. This study is based on the Principle Component Analysis(PCA) that extracts the system's evaluation factors effectively, as the poll was targeted to an expert group composed of the professionals in universities and research institutes of the related field such as local and central government offices, district research labs related to the development and usage as well as research labs and environment organizations related to preservation.

\section{Conflict Mediation Status and Evaluation Factors Acquisition Necessity}

\subsection{Domestic and Foreign Cases}

\section{1) U.S. Case \& Issues}

The L.S. broadly defines the coast legally in the national level, and uses the method of setting detailed boundaries when establishing coastal management plans at the federal and local government. Therefore, the detailed range of the coast is set according to the federal government coastal management plan, and there does not exist a single concept for the coast in the U.S. law system.

On the other hand, the U.S. coast range setting status is set to 3 miles for State jurisdiction for coastal sea areas, and various elements for coastal land areas, ranging from $100 \mathrm{ft}$ from the coast, to the entire state area as maximum. Especially, activities such as garbage processing, mineral mining, oil \& chemical processing, transport \& storing, power plants etc. that occur within the state boundaries, are set as permission targets for the coastal management committee even if they occur in the land area. Currently, the U.S. coast is managed by the National Estuary Program which is driven in another direction by the EPA, the National Marine Sanctuary Program \& the National Estuarine Research Reserver Program, and the Coastal Zone
Management Program which is composed around NOAA.

Some of the strong points of the U.S. coastal management elements, is the continuous policy establishment \& operations, and the maintenance of the consistency of the policies and the links to the various coast related laws. Also, the L.S. conflict resolution issues show the adequate efforts for the conflict resolution between the parties involved, a timely role as the mediator for the conflict mediation, and the ozeration of a pilot project and dissension program for the conflict mediation.

\section{2) Japan Case \& Issues}

Japan has rich beaches and long bays, but were heavily damaged due to farming and industrial land usage, port extensions, resort development etc. Japan's beach area is $0.15 \%$ of the country's size covering 51,462 ha according to the 1998 3rd national environment ecosystem survey; which is $40 \%$ lower that the 83,000ha surveyed in 1945 .

Japan's reclamation project has a history of a thousand years, however due to the beach preservation act snce the late 1970s, the speed of development has reducied, and active researches for the restoration of the beach ecosystem is in progress at the same time, and this has simularities with the situation of the coast development of our country in many aspects. In other words, the fact that there exists environment problems due to reclamation and the coastal area development demand is an important issue in the conflict similar to our country. The Japan conflict case shows that problems occur due to the absence of an integrated mediation effort between the interest parties, and the aftereffects are large due to the temporary environment effect evaluations of the administration department, and the environment damages are large according to the one sided development logic.

\section{3) Domestic Status \& Issues}

When observing the domestic coastal conflict types, there are the conflicts of development demands for land extension \& preservation demands to prevent the destruction of the coastal ecosystem, urban planning and port planning conflicts and various conflicts of plans due to laws, interest relations for marine resources and reclamation for industrial complex construction, and conflictions from ocean floor mineral resources development activities and coastal spatial usage.

Also, when observing the conflicts between users and government organizations, user based conflicts are generally competing over marine space, space \& facilities of the coastal land area, resources, and occuring because of the negative effects to the environment from the specific usage. 
Also, factors of government based conflicts were due to different law bases \& department tasks, differences in administration execution between organizations, different external related interest groups and lack of communication. In order to resolve these complex conflicts, various political systems and related programs are necessary, however, we have various goverment offices and departments related to the coastal management, and the related laws are all different, resulting in redundancy, confliction, and inharmony. In other words, there exists more than 45 separate laws that are divided into 9 central and city/province departments(Lee J. H., 1998).

\subsection{Evaluation Factors Acquisition Necessity}

There are some conflict areas that have been recently solved through the mediation among the interested parties. Such examples are shown in the cases of Kumgang rivermouth, Sunchon bay, and Seoko lake, but there still exists serious conflicts without a detailed solution of development, usage, and preservation, is the Sihwa lake area. Therefore, the description of the conflict resolution technique is necessary at first. The following is a list of the sequence of the conflict mediation strategy.

1. Verify the suitability of the national base plan and the law criteria

- At first, decide whether it is adequate with the objectives and policy direction of the 'Ocean Korea 21' and 'Integrated Coastal Management Plan' which is Korea's Marine Development Base Plan

Secondly, apply the priority ranking of higher base laws for the proposed plans according to the special and higher laws and newer law principle.

2. Extract a consultation proposal through an adequate conference and mediation procedure between the parties

- Search an altemate proposal that has converged the opinions of the interest parties by applying the proposal of finding an agreement through the mediation procedure or a 1:1 agreement as much as the number of possibilities considering the logical basis, law propriety, social response forming, and economic value etc. in the case where it is difficult to screen priority in the conflict of the interest parties about the coastal conflicts.

- It is possible to elect a mediator that fully understands the plan contents to solve the coastal usage conflict through the agreement of the interest parties during the 1:1 agreement procedure, and the elected mediator should carry out the agreement plan until the final proposal is acquired through a face-to-face interview for each item on the plan using a negotiated planning method.

Afterwards, the plan should be edited through a new agreement procedure based on the evaluation of the proposal setting to find the mediation direction that is adequate according to the evaluation mechanism, from the field's professionals that the interest group recognizes in the Sihwa lake area, which is currently not settled of a detailed proposal to solve the conflict.

However, in order to apply the evaluation method, it is necessary to develop the standardized evaluation factors that can objectively evaluate the proposals that are in conflict, but currently there is no such research applied in that sense. Therefore, this research uses the PCA method that can extract the evaluation factors of the system to extract the evaluation mechanism of the conflict of the coastal area.

\section{Evaluation Base Factor Survey}

\subsection{Literature survey}

Looking at the literature, four classifications are worthy of consideration, at least as a preliminary approach. They are presented in Table 1 . These classifications are characterized by multi-feature contents: (i) Couper includes sectors of economic activity(navigation and communications, research, recreation and others) as well as categories of natural resources(biological, mineral, energy resources) and waste disposal. (ii) Sorensen's framework reveals a pragmatic sectors(tourism, ports, agriculture and others): the rest is concerned with resource exploitation(energy, water) and environmental protection (natural area protection systems) and environmental protection(natural area protection systems). (iii) Also Pido and Chua's framework includes activity sectors and natural resources. (iv) Vallega's framework includes resources(biological, mineral, energy resources), activity sectors(seaports, shipping, air transportation), man-made structures and environmental protection(Couper, C. D., 1983), (Sorensen, J. C., 1990), (Pido, M. D., Chua T. E., 1992), (Vallega, A., 1992).

Otherwise, The Lynean Gulf programme aims at providing sustainable development of biological resources vis-a-vis the increasing human pressure on the coastal zone. The Hawaii programme aims at more diversified economic organisation, in which the exploitation of mineral resources and energy production are the manifestations of diffusing manufacturing function in the coastal zone. The Mediterranean Action Plan is concerned with the 
uniqueness of coastal areas subject to increasing human pressure, economically diversified regional systems and unusual maritime traffic(Hawaii Ocean and Marine Resources Council, 1991), (National Economic Development Authority, 1992), (Mediterranean Action Plan, 1993).

Table 1 Coastal use frameworks by literature

\begin{tabular}{|c|c|}
\hline $\begin{array}{c}\text { Couper }^{1 \prime} \\
(1983)\end{array}$ & $\begin{array}{l}\text { Navigation and communication, Mineral } \\
\text { and energy resources, Biological } \\
\text { resources, Waste disposal and Pollution, } \\
\text { Strategy and defence, Research, } \\
\text { Recreation, Environment, Management }\end{array}$ \\
\hline $\begin{array}{c}\text { Sorensens }^{21} \\
(1990)\end{array}$ & $\begin{array}{l}\text { Fisheries, Natural area protection } \\
\text { systems, Water supply } \\
\text { Recreation development, Tourism, Port } \\
\text { development, Energy development, Oil } \\
\text { and toxic spill contingency planning, } \\
\text { Industrial siting, Agricultural } \\
\text { development, Mariculture development }\end{array}$ \\
\hline $\begin{array}{c}\text { Pido and Chua }{ }^{3 \prime} \\
\text { (1992) }\end{array}$ & $\begin{array}{l}\text { Agriculture, Fisheries and aquaculture, } \\
\text { Infrastructure, Mining, Ports and } \\
\text { harbours, Industry, Tourism, Urban } \\
\text { development, Forestry, Shipping }\end{array}$ \\
\hline $\begin{array}{c}\text { Vallega } \\
\text { (1992) }\end{array}$ & $\begin{array}{l}\text { Seaports, Shipping, carriers, Shipping, } \\
\text { Routes, Shipping navigation aids, Sea } \\
\text { pipelines, Cables, Airtranportation, } \\
\text { Biological resources, Hydrocarbones, } \\
\text { Metalliferous, Renewable energy } \\
\text { sources, Defence, Recreation, Waterfront } \\
\text { man-made structures, Waste disposal, } \\
\text { Research, Archaeology, Environmental } \\
\text { protection and preservation }\end{array}$ \\
\hline
\end{tabular}

Source : 1) Couper, C. D. (1983), Atlas of the Oceans, Times Books, London.

2) Sorensen, J. C. (1990), Institutional Arrangements for Managing Coastal Resources and Environments, National Arrangements for Managing Coastal Resources and Environments, National Park Service, US Department of Interior, US Agency for International Development, Washington DC.

3) Pido, M. D., Chua T. E. (1992), A Framework for Rapid Appraisal of Coastal Environments, International Center for Living Resources Management, Manila.

4) Vallega, A., (1992), Sea management. A theoretical approach, Elservier Applied Science,
London.

Table 2 Coastal use frameworks by literature

\begin{tabular}{|c|c|}
\hline $\begin{array}{c}\text { Hawaii Ocean Resources } \\
\text { Management Plan } \\
\text { (1991) }\end{array}$ & $\begin{array}{l}\text { Research, Recreation, Harbjurs, } \\
\text { Fisheries, Marine ecosystem, } \\
\text { Beaches and coastal ercsion, } \\
\text { Waste management, Enırgy, } \\
\text { Marine Minerals }\end{array}$ \\
\hline $\begin{array}{l}\text { Lingayen Gulf Coastal } \\
\text { Area } \\
\text { Management Plan } \\
\text { (1992) }\end{array}$ & $\begin{array}{l}\text { Fisheries, Alternative livelihood } \\
\text { for fishing families, Aquaculture, } \\
\text { Environmental quality, Critical } \\
\text { habitats, Linked habitats }\end{array}$ \\
\hline $\begin{array}{c}\text { Mediterranean Action } \\
\text { Plan }^{3 \text { ) }} \\
\text { (1993) }\end{array}$ & $\begin{array}{l}\text { System of Urban and rural } \\
\text { centers, Open spaces, Agricultural } \\
\text { land, Forestry, Mining, Industrial } \\
\text { areas, Residential areas, Tourism } \\
\text { and recreational areas, Sea uses, } \\
\text { Transport corridors and areas, } \\
\text { Other infrastrictures }\end{array}$ \\
\hline
\end{tabular}

Source : 1) Hawaii Ocean and Marine Resources Council (1991), Hawaii Ocean Resources Management Plan, Technical Supplement, Hawaii Ocean and Marine Resources Council, Honolulu.

2) National Economic Development Authority (1992), The Lingayen Gulf coastal area management plan, Technical Reports, International Center for Living Resources Management, Manila.

3) Mediterranean Action Plan (1993), Integrated coastal management, International Center for Living Resources Management, Unpublished Reports, Manila.

\subsection{Evaluation Basic Factor Research}

In order to extract the factors that should be included when considering the conflict mediation in the coastal usage, a basic factor was extracted through the consulting of an expert group, expert delphi investigation, and professional references. The expert group that was used in the basic factor extraction process were composed of 36 people, and they included research labs related to environment preservation, environment organizations, expert groups including local citizens, government agencies related to the development and usage, expert groups including local research labs, and universities and labs related to the field. According to this research, a total of 68 factors were extracted. Also, to verify the objectivity of the ex.tracted factors, a 17 page survey was carried out targeted to a professional group of 40 by internet, fax and mail. The survey's objective was to understand the mandatory factor insert and approximate level structure, integrate redundancy factors, and verify adequateness of the extracted factors, and was able to acquire 6 high categories representing the 
minute factors, which are the development factor, preservation factor, usage factor, environment factor, law/regulation factor, development profit distribution \& dispute mediation factor, and most of the sub elements included 35 complex factors through integration and delete insert process. Table 3 shows the complex factors through 35 samples, and are listed without any priority or specific meaning in order.

\section{Evaluation Factors Extraction}

\section{1 PCA Method Application}

PCA(Principle Component Analysis) was adopted to construct the evaluation factors based on the complex components resulted from 1st questionnaire survey of the study. 2nd questionnaire survey for PCA was conducted via internet. As a result, 25 responding questionnaires were returned from 38 requested experts. At first, complex components were utilized to develop the 35 by 35 correlation matrix.

There is no need to do standardization because the value of each correlation matrix was relatively assigned in the range between $[0,1]$. Then, eigen-values from correlation matrix were calculated for the grouping of complex components of PCA. The calculated values of $\lambda$ are listed in rank which are $0.38,0.33,0.30,0.41,0.43,0.27,0.23,0.21$, $0.16,0.15,0.13,0.48,0.08,0.50,0.06,0.03,0.54,-0.01,0.64$, $-0.09,-0.10,0.72,0.72,-0.21,0.87,1.05,1.14,1.20,1.27$,

Table 3 Complex factors for Evaluation Structure

1. road facilities, improvement of life qualities, building housing area

2. minimization of cultural assets destruction

3. prevention of seawater going over

4. regional development followed by building tourist places and hydrophile spaces

5. securing water sources and others.

6. habitats of seasonal birds, minimizing of damage of tidal conservations and cultural properties.

7. minimizing marine-environmental pollution of presenting, conservation of marine-fisheries

8. minimizing damage to natural scenes

9. minimization of cultural assets destruction

10. ecosystem damage decrease, preparing security mechanism

11. worth of estuary silt

12. functioning of estuary silt for protecting kinds and varieties of marine resources

13. Ports industrial complex industrial use of logistics complex

14. hydrophile property and leisure use such as tourism, leisure, park construction,

15. housing complex with pleasantness

16. facilities of eco-health and education such as eco-type park

17. increase shrinking facility sites

18. expansion of public facility sites

19. air and water pollution

20. changing index of land use, urbanization rates, swamp cultivation rate

21. societal, economical index/rate if population increase, employment rate, land price

22. index of ecological varieties, land and marine ecosystems

23. proposals of environment-friendly use

24. coordination of laws related to national land use plans, coastal management laws related management

25 difficulties and conflicts of cooperation among related department

26. development competition of local autonomous entities

27. conflicts of relevant laws, plans of cities and ports, conflicts between demands for development and conservation ,land reclaiming conflicts for building water resources conservation and industrial complex

28. jointing of Ramsa agreement

29. monetary compensation

30. higher priority of installment sale to people who lived in reclamation land

31. development support of corresponding area

32. increase of creating employment and support

33. technical enforcement for prevention of evironment pollution

34. enhancement of cooperative mechanism among committee type autonomous entities

35. introduction and application of similar cases of precedents 
$-0.45,1.34,-0.74,1.63,2.60,18.72$. An eigen-vector was calculated from these values. Figure 1 was obtained by setting $\lambda 35$ and $\lambda 34$ that have maximum eigen values as an axis of Principle component and displaying the grouped corresponding eigen-vector values on the coordinated plane. The result of this grouped display is as follows. The group of G1, G2 and G3 are roughly divided into the following three categories of Preservation and Environmental Aspects(Category 1) Allocation of Development Profits (Category 2) and Development and Use Aspects(Category 3) but the group of G4 does not show clear boundary due to the mix of attributes of the three categories. The reason of this result is shown from the eigen-value. The sum of first axis of principle component and second axis of principle component is only 21.32 and the cumulative ratio is not more than $60 \%(21.32 / 35)$. This represents that there is no distinct principle component resulting unclear group.

In this case, a clear group can be obtained by adopting the a-cut method from Fuzzy Relation. At first, the distance between the factor loading points are rreasured from the Space of Principle component. Then a binary matrix between peak nodes showing either the signnificant

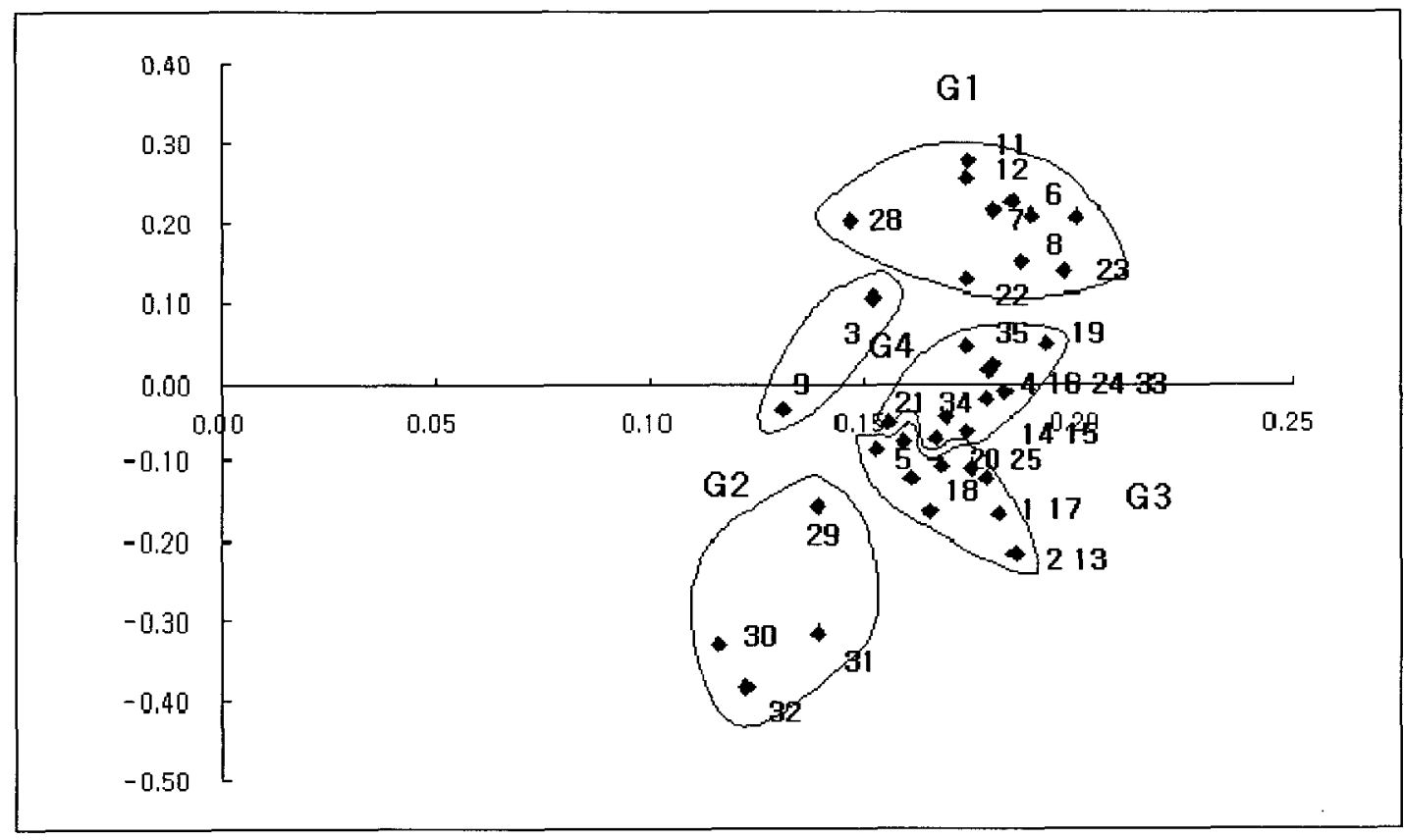

Fig. 1 1th Result by PCA Method

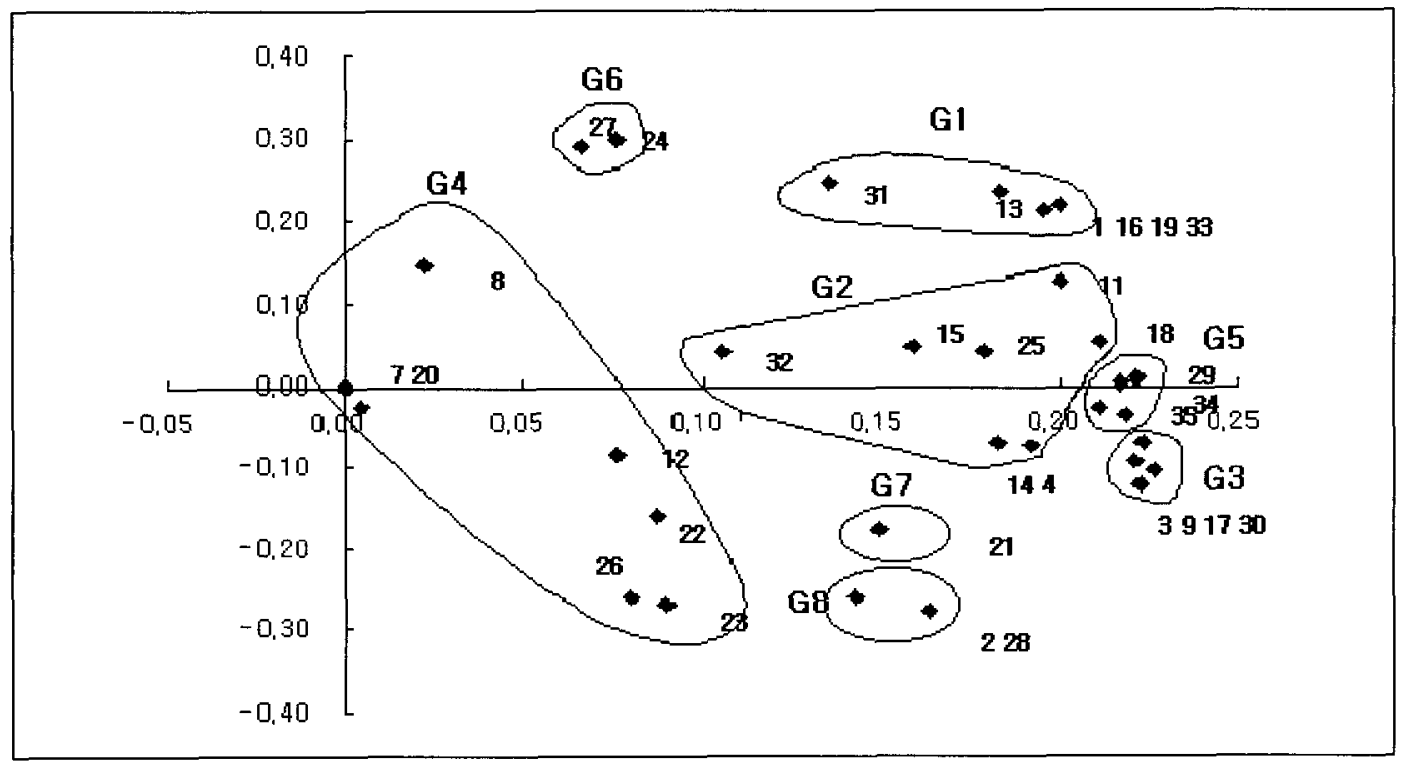

Fig. 2 2nd Result by PCA Method 


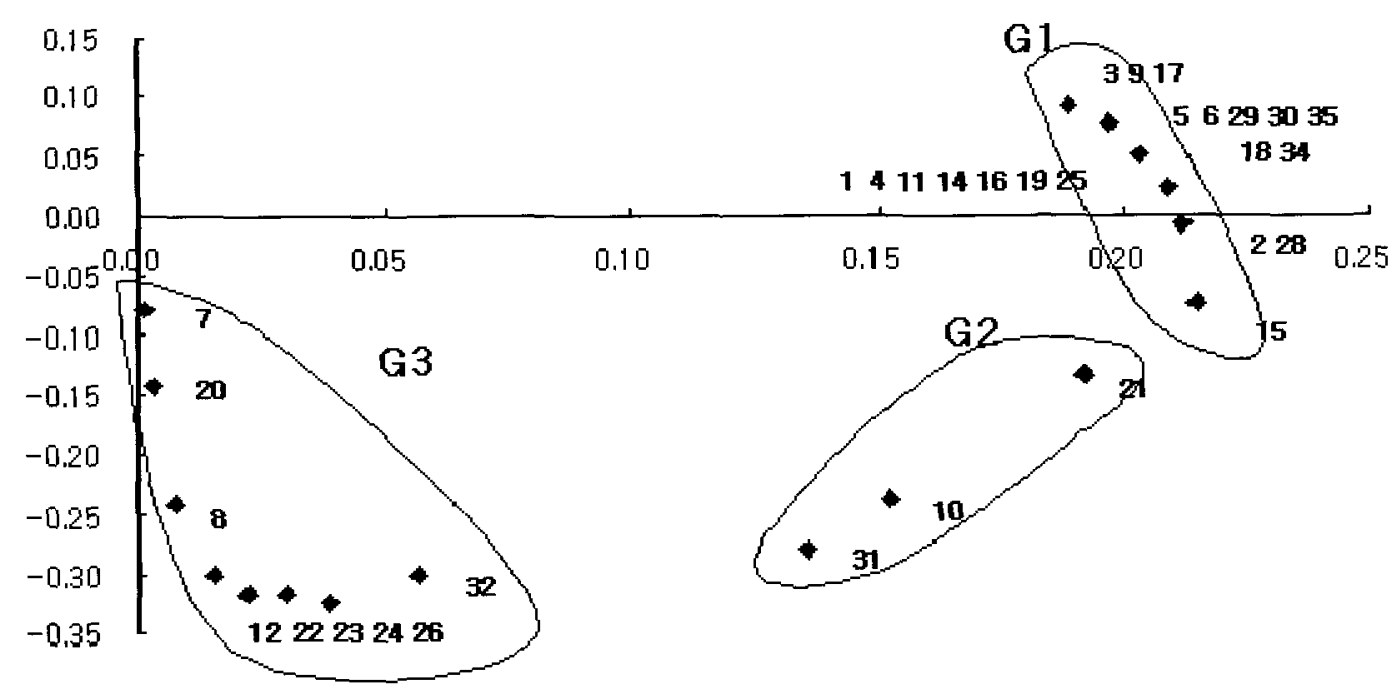

Fig. 3 3rd Result by PCA Method

relationship if the distance is more than the average or the insignificant relationship if the distance is less than the average is developed. Finally, PCA is repeated to this binary matrix. This process can be continued until the clear grouping. The eigen-values from binary matrix were calculated from this process and the calculated values of $\lambda$ are the value of 0.00 from No. 1 to No. 6 and the rest are $1.00,0.12,0.18,0.32,0.39,0.60,0.69,-0.33,-0.48,-0.58$, $-0.78,1.02,-0.90,1.16,1.28,-1.11,-1.51,1.77,-1.94,-2.90$, $2.09,2.28,-2.65,2.64,2.92,-3.39,7.02,7.65,22.27$. Figure 2 was obtained by setting $\lambda 35$ and $\lambda 34$ that have maximum eigen values as an axis of Principle component and displaying the grouped corresponding eigen-vector values on the coordinated plane.

From these grouped result, G1 and G2 are clearly categorized in the Development and Use Aspects and G3, G4 and G6 are in the Preservation, Environment, Law and Institutional Aspects. However, G5 can be allocated either in the Allocation of Development Profits or Social and Economic Aspects due to the unclear boundary of the group.

Here, G8 is shown as a separate group because many complex components has correlation among the components but this G8 couldn't be considered as a separate group. The sum of first axis of principle component and second axis of principle component is 29.83 and the cumulative ratio is about $85 \%(29.83 / 35)$. This shows that the characteristics of the correlation matrix is well represented.

In addition to these analyses, another PCA was tried to make the clear boundary of G5, G7 and G8 but Figure 3 shows that correlation among the complex components are mostly ignored as a result. From these grouped result, G1 and G2 are clearly categorized in the Development and Use
Aspects and G3, G4 and G6 are in the Preservation, Environment, Law and Institutional Aspects. However, G5 can be allocated either in the Allocation of Development Profits or Social and Economic Aspects due to the unclear boundary of the group. Here, G8 is shown as a separate group because many complex components has correlation among the components but this G8 couldn't be considered as a separate group.

This shows that the characteristics of the correlation matrix are well represented. In addition to these analyses, another PCA was tried to make the clear boundary of G5, G7 and G8 but Figure 3 shows that correlation among the complex components are mostly ignored as a result.

From these analyses, Figure 2 shows that there is high relationship in G1 as a group of Development, Law and Institutional Aspects, G2 as a group of Allocation of Development Profits, and G3 as a group of Preservation \& Environment. Therefore, it can be concluded that the result of Figure 2 is the most appropriate group of the complex components in order to determine the evaluation structure of conflict mediation model.

In summary, the complex components can be grouped based on the similarity of each attribute resulting G1 and G2 as a representative group of Development and Use Aspects, G3 and G4 as Preservation and Environmental Aspects, G5 as Allocation of Development Profits, G6 as Law and Institutional Aspects, G7 as Social and Economic Aspects.

\subsection{Evaluation Factors of the Conflict Mediation Model}

As above result in mind, evaluation factors of the conflict mediation model can be shown as below table. 
Table 3 Evaluation Factors

\begin{tabular}{|c|c|c|}
\hline $\begin{array}{l}\text { Representative } \\
\text { Attribute name }\end{array}$ & Explanation of Attributes & Detailed Attributes \\
\hline Development and Use & $\begin{array}{l}\text { Attributes composed of components } \\
\text { of usage, development of road } \\
\text { construction, to meet other various } \\
\text { needs, industrial use of subject area } \\
\text { and use for life improvement, }\end{array}$ & $\begin{array}{l}\text { Ports industrial complex industrial use of logistics complex, } \\
\text { development support of corresponding area, road facilities } \\
\text {,improvement of life qualities, building housing area, facilities of } \\
\text { eco-health and education such as eco-type park, hycrophile } \\
\text { property and leisure use such as tourism, leisure, park } \\
\text { construction, housing complex with pleasantness, regional } \\
\text { development followed by building tourist places and hycrophile } \\
\text { spaces, life use for building life environment condition, expansion } \\
\text { of public facility sites, increase of creating employment and } \\
\text { support, difficulties and conflicts of cooperation among related } \\
\text { department, securing water sources and others, worth of estuary } \\
\text { silt, air and water pollution, technical enforcement for prevention } \\
\text { of evironment pollution. }\end{array}$ \\
\hline $\begin{array}{l}\text { Preservation and } \\
\text { Environmental Aspects }\end{array}$ & $\begin{array}{l}\text { Components related to conservation } \\
\text { such as nature of subjected area, } \\
\text { ecological and cultural properties } \\
\text {;attributes composed of combined } \\
\text { components of environmental aspects. } \\
\text { such as environment-friendly usage } \\
\text { plans. }\end{array}$ & $\begin{array}{l}\text { habitats of seasonal birds, minimizing of damage of tidal } \\
\text { conservations and cultural properties. proposals of } \\
\text { environment-friendly use, minimizing damage to natural scenes, } \\
\text { minimizing marine-environmental pollution of presenting, } \\
\text { conservation of marine-fisheries, changing index of land use, } \\
\text { urbanization rates, swamp cultivation rate, functioning of estuary } \\
\text { silt for protecting kinds and varieties of marine resources, index } \\
\text { of ecological varieties, land and marine ecosystems, development } \\
\text { competition of local autonomous entities, unlawful intervention of } \\
\text { the third parties such as environment entities, Prevent:on of } \\
\text { seawater going over, minimization of culturl assets destruction, } \\
\text { increase shrinking facility sites, higher priority of receive land } \\
\text { allotment that accure to people who lived in reclamation land. }\end{array}$ \\
\hline $\begin{array}{l}\text { Law and Institutional } \\
\text { Aspects }\end{array}$ & $\begin{array}{l}\text { Attributes related to conflicts and } \\
\text { coordination on the relevant laws and } \\
\text { considering the use of subjected area. }\end{array}$ & $\begin{array}{l}\text { conflicts of relevant laws, plans of cities and ports, ccinflicts } \\
\text { between demands for development and conservation ,land } \\
\text { reclaiming conflicts for building water resources conservation and } \\
\text { industrial complex, coordination of laws related to national land } \\
\text { use plans, coastal management laws related management, lack of } \\
\text { legal and institutional mechanism for conflict coordination, } \\
\text { insufficient cooperation of officials in charge of development and } \\
\text { conservation due to departmental selfishness. }\end{array}$ \\
\hline $\begin{array}{c}\text { Social and Economic } \\
\text { Aspects. }\end{array}$ & $\begin{array}{l}\text { Attributes related to social and } \\
\text { economic aspects such as population, } \\
\text { employment, land price of subject } \\
\text { area. }\end{array}$ & $\begin{array}{l}\text { societal, economical index/rate if population increase, employment } \\
\text { rate, land price, ecosystem damage decrease, preparing security } \\
\text { mechanism, visitor's expanse increase, increasing fares of lodging } \\
\text { and facility use }\end{array}$ \\
\hline $\begin{array}{c}\text { Allocation of } \\
\text { Development Profits }\end{array}$ & $\begin{array}{l}\text { Attributes related to variouos } \\
\text { compensation and sharing of profits } \\
\text { followed by the use of subjected } \\
\text { area.. }\end{array}$ & $\begin{array}{l}\text { monetary compensation, introduction and application of similar } \\
\text { cases of precedents, enhancernent of cooperative mechanism } \\
\text { among committee type autonomous entities, local residents' } \\
\text { excessive demand for compensation, avoidance of discussion } \\
\text { among residents, social interest groups, public institutions due to } \\
\text { mutual distrusts, use of mutual expert research institute, } \\
\text { judgements by judicial courts }\end{array}$ \\
\hline
\end{tabular}

\section{Conclusion}

Our country does not have a well formed coast related law relation or consistency and continuity of policy, interest tanglement resolution programs or active mediation to solve the conflicts such as the developed countries. Despite these facts, various opinion conflicts are arising between the interest groups for the usage of the coastal area, and this often brings great negative effects to the society. In order to remedy this problem, this research is aimed to propose an evaluation standard that is objective and standardized to extract a reasonable decision mechanizm that is reasonable to the areas that conflicts are not yet settled through the mediation tasks in using the coastal areas. This research adopted the PCA methodology via 2 surveys of expert groups involved in the conflict through phone, mail and intenet. The results are as follows.

It was noticeable that the objective evaluation factors for conflict resolution is composed of 35 complex minute elements and a total of 5 representative elements. The following describes the extracted representing elements. 
1) The representative element of 'Development and usage factor for the various necessities of target area industrial usage, subsistence enhancing usage, road construction etc.' extracted as the 'development and usage aspect'.

2) A element composed of 'Complex factor related to the environmental aspect of the nature, cultural assets of the target area and the preservation of the related factors and environment-friendly usage scheme proposal' extracted as the 'preservation and environment aspect'.

3) 'Related elements for the mediation of the related laws considering the target area usage' extracted as the 'law/policy aspect'.

4) 'Related elements for the social economic aspect of the populuation, employment and land value of the target area/ extracted as the 'social/economic aspect'.

5) 'Related elements of various compensation and profit distribution according to the target area usage.

The result of this research is expected to play a significant role in resolving conflicts by extracting an evaluation mechanism for the mediation activity and reasonable decision making when conflicts occur in the coastal area, especially in Korea where it is difficult to find such a resolution. However, there needs more post research projects which remains as the limits of this research such as the massive information acquirement of the domestic/foreign related coastal conflicts, and a strict character extraction through the expansion of the population.

\section{Acknowledgements}

This paper is supported by CIIPMS(Center for Intelligent and Integrated Port Management Systems).

\section{References}

[1] Bower B. D., Turner R. K., (1998), Characterizing and analysing benefits from integrated coastal management, Ocean \& Coastal Management, 38, 41-66.

[2] Cicinsain B. (1992), Multiple use conflicts and their resolution : Toward a comparative research agenda, Elservier Applied Science, London.

[3] Couper, C. D. (1983), Atlas of the Oceans, Times Books, London.

[4] Hawaii Ocean and Marine Resources Council (1991), Hawaii Ocean Resources Management Plan, Technical Supplement, Hawaii Ocean and Marine Resources Council, Honolulu.
[5] Jo D. O. (2001), A Study on Evaluation Factors of ICZM in Korea, Journal of the Society of Maritime Safety, 7(2), 67-87.

[6] Keum J. S., Yoon M. O. (1998), A Study on the Strategy for Construction of Integrated Coastal Zone Management System, Journal of the Mokpo Maritime University, 6(2), 72-92.

[7] Kim K. S. (1999), The Plan and Subjects of Management for Use, Development and Conservation of Coastal Zone in the Southwest Area of Korea , Journal of the Mokpo Maritime University, 7(2), $31-53$.

[8] Lee J. H. (1998), Integrated Coastal Management, Journal of the Architecture, 46(4), 19-27.

[9] Mediterranean Action Plan (1993), Integrated coastal management, International Center for Living Resources Management, Unpublished Reports, Manila.

[10] National Economic Development Authority (1992), The Lingayen Gulf coastal area management plan, Technical Reports, International Center for Living Resources Management, Manila.

[11] Park C. H., Rho H. S., Yang W. J. (1998), A Study on Efficient management at coastal zone in Port of Busan, Journal of the Korean Institute of Port Research, 12(1), 1924 .

[12] Pido, M. D., Chua T. E. (1992), A Framework for Rapid Appraisal of Coastal Environments, International Center for Living Resources Management, Manila.

[13] Schneider P., Tohn E. (1985), Success in negotiating environmental regulations , Environmental Impact Assessment Review, 5, 66-77.

[14] Sorensen, J. C. (1990), Institutional Arrangements for Managing Coastal Resources and Environments, National Arrangements for Managing Coastal Resources and Environments, National Park Service, US Department of Interior, US Agency for International Development, Washington DC

[15] Vallega, A., (1992), Sea management. A theoretical approach, Elservier Applied Science, London.

[16] Young M. D. (1992), Sustainable Investment and Resources. Equity, Environmental Integrity and Economic Efficiency, UNESCO and The Parthenon Publishing Group, Paris.

Received 22 May 2003

Accepted 5 August 2003 